\title{
IMPACT OF EDAPHIC HYDROCARBON POLLUTION ON THE MORPHOLOGY AND PHYSIOLOGY OF PEA ROOTS (PISUM SATIVUM L.)
}

\author{
BELLOUT, Y. ${ }^{1}-$ KHELIF, L. ${ }^{2}-$ GUIVARCH, A. ${ }^{3}-$ HAOUCHE, L ${ }^{4}-$ DJEBBAR, ${ }^{2}{ }^{2}-$ \\ CAROL, $\mathrm{P}^{3}-$ ABROUS BELBACHIR, $\mathrm{O}^{2 *}$ \\ ${ }^{I}$ Department of Biology, Faculty of Sciences, UniversityMhamad Bougara Boumerdes- Algeria \\ ${ }^{2}$ Laboratory of biology and Physiology of organisms, Faculty of Sciences, University of \\ Sciences and Technology Houari Boumediene- BP 32 El Alia-16111-Algeria \\ ${ }^{3}$ Sorbonne Universités, UPMC Univ. Paris 06, 4 Place Jussieu, 75005, Paris, France \\ ${ }^{4}$ Scientific Institute of Public Service (ISSeP)-Rue de la platinerie, Colfontaine-Belgium \\ *Corresponding author \\ e-mail: oabrous@yahoo.fr \\ (phone +213-21-24-72-17; fax +213-21-24-79-50) \\ (Received $6^{\text {th }}$ Aug 2015; accepted $26^{\text {th }}$ Feb 2016)
}

\begin{abstract}
Exposure to persistent organic hydrocarbon pollutants can have deleterious effects on the growth, physiology and anatomy of plants. Sand collected at an oil-drilling quagmire in southern Algeria was analyzed by GC-FID and found to contain $18 \mathrm{mg} \mathrm{Kg}^{-1}$ hydrocarbons. Pisum sativum L. (pea) plants were grown in laboratory conditions in sandy soil from the site. Plants growing in hydrocarbon polluted sandy soil had shorter primary roots and fewer lateral roots than control plants growing in non-polluted sandy soil. However lateral root dry weight was $35 \%$ higher than control. Pollutant-induced oxidative stress on pea roots resulted in lipid peroxidation and accumulation of MDA, $\mathrm{H}_{2} \mathrm{O}_{2}$ and $\mathrm{O}_{2}^{-}$in root tips. Enzymatic detox activities of superoxide dismutase and peroxidase were also over $40 \%$ higher in plants growing on polluted soil than in controls. The anatomy of pea roots was also affected by hydrocarbonpolluted soil, because xylem vessel differentiation was delayed and an unusual supplementary cell layer was formed in the endoderm. These data suggest pea plants adapt morphologically and anatomically to polluted soil.
\end{abstract}

Keywords: hydrocarbons, pea roots, growth, oxidative stress, anatomy

\section{Introduction}

Since the mid-1980s, hydrocarbon contamination has become a critical environmental problem worldwide due to its adverse effects on the environment and health ( $\mathrm{Li}$ et al., 1993). In Algeria, petroleum is one of the main energy resources. Petroleum exploration can cause soil pollution because drilling mud is stored in quagmire spill sites so the soil surface becomes impregnated with total petroleum hydrocarbons (TPHs). TPHs are complex mixtures of various hydrocarbons that can be found at petrochemical sites and storage areas, waste disposal pits, refineries and oil spill sites (McElroy et al., 1989).

Plants are a dominant biotic component of ecosystems and as sessile organisms; they can be subjected to long-term pollution from hydrocarbons (McCarthy and Tschaplinski, 1991). Organic pollutants are able to penetrate plant organs through different mechanisms (Gao and Zhu, 2004). In plant tissues, organic pollutants can migrate from roots to leaves, and within the plant organs, they can be modified by conjugation, hydroxylation and by 
cytochrome containing monooxygenase enzymes (Korte et al., 2000). Plant growth is affected by decrease of biomass in oiled areas (Culbertson et al., 2008). For maize germination and growth in crude-oil polluted soil, the effect is proportional to the concentration of the crude oil in the environment (Ogboghodo et al., 2004). The considerable effect of polycyclic aromatic hydrocarbon fluoranthene (FLT) exposure was to inhibit germination of seeds, retard growth and affect root morphology (Kummerova et al, 2012). Anoliefo (1991) found evidence of cell disruption in roots and other organs and the presence of oil films in the epidermal and cortical regions of the root, stem, and leaves. Crude oil induced environmental stress in the seedlings causing inhibition of total amylase and starch phosphorylase activities and mitotic activity of root meristems (Achuba, 2006). The harmful effects of petroleum hydrocarbons in soils include inhibition of seed germination, reduction of photosynthetic pigments, slowdown of nutrient assimilation and shortening of roots and can disrupt the plant root architecture (Smith et al., 2006). Some other workers have also used anatomical changes to monitor environmental pollution (Gill et al., 1992). Petroleum hydrocarbons were reported to alter the shape and size of parenchyma tissue and reduce the intercellular space in the cortex of the stem and roots (Omosum et al., 2008).

In polluted soils, plants may experience a combined stress from nutritional deficiency and chemical toxicity. Indeed, abiotic stress such as that caused by polycyclic aromatic hydrocarbon exposure can also stress plants by generating reactive oxygen species (ROS) (Sun et al., 2002). ROS such as superoxide radical $\left(\mathrm{O}_{2}^{-}\right)$, hydrogen peroxide $\left(\mathrm{H}_{2} \mathrm{O}_{2}\right)$ and hydroxyl radical $\left(\mathrm{OH}^{-}\right)$, are generated as by-products of normal metabolism in different subcellular compartments. Moreover, the imposition of biotic or abiotic stress may give rise to an excessive concentration of ROS, resulting in oxidative damage at cellular level that can be mitigated and repaired by a complex antioxidant system (Romero-Puertas et al., 2007). Stress induced ROS accumulation is counteracted by enzymatic antioxidant systems that include a variety of scavengers, such as superoxide dismutase (SOD), ascorbate peroxidase (APX), peroxidase (POD), glutathione S-transferase (GST), catalase (CAT) and non-enzymatic low molecular metabolites (Mittler et al., 2004).

The impact of hydrocarbon contaminants on plant roots, which are in direct contact with the pollutants, is not as well documented as the effect on leaves or photosynthesis. For this reason, we aimed to evaluate the effect of hydrocarbons from an edaphic pollution on the growth of pea roots (Pisum sativum L.) in controlled laboratory conditions. We observed changes in $\operatorname{ROS}\left(\mathrm{O}_{2}^{-}, \mathrm{H}_{2} \mathrm{O}_{2}\right)$ and ROS detoxifying enzymes, MDA levels were enhanced in pea roots growing in polluted soil. Furthermore an unexpected morphological adaptation was observed at the level of the endoderm cell layer.

\section{Materials and methods}

\section{Soil}

Soil samples were collected in the region of Hassi Messaoud-Ouargla province of southern Algeria. Contaminated soil was sampled at the site of a disused oil quagmire. Control soil was sampled at a site two kilometers from the quagmire. Three soil samples were collected at $0-30 \mathrm{~cm}$ depth using a stainless steel sampler. The three samples were mixed to form a single sample that was air-dried and then sieved $(2 \mathrm{~mm}$ sieve) before analysis. 


\section{Hydrocarbon analysis}

Before hydrocarbon measurement soil samples were chemically dried, by adding $\mathrm{Na}_{2} \mathrm{SO}_{4}$. Analysis of hydrocarbons in soil was conducted in the ISSeP laboratory (Scientific Institute of Public Service, Colfontaine, Belgium) using techniques developed in the laboratory.

\section{Polycyclic aromatic hydrocarbon (PAH) content in soil samples}

The 16 PAH congeners listed as priority pollutants by the US Environmental Protection Agency (US-EPA) were analyzed in the soil samples. The extraction of these compounds was performed by the Accelerated Solvent Extractor (ASE) technology (Dionex ASE 350), allowing a solid/liquid extraction with dichloromethane at $150{ }^{\circ} \mathrm{C}$ at a pressure of $1500 \mathrm{psi}$. The dichloromethane extract was extracted with hexane and cleaned up with aluminium oxide. The sample was extracted with acetonitrile and the extract was concentrated at room temperature under a gentle stream of nitrogen. PAHs were then separated by ultra-performance liquid chromatography (UPLC) and detected using a fluorescence detector with appropriate excitation and emission wavelengths for the $15 \mathrm{PAH}$ and a diode array detector for acenaphthylene. Quantification was performed by external standard calibration. Ultra performance liquid chromatography (UPLC) was performed with a $1.8 \mu \mathrm{m}, 2.1 \mathrm{~mm}$ ID $\times 100 \mu \mathrm{m}$ AZE-PAH column at a flow rate of $0.4 \mathrm{ml} / \mathrm{min}$. The mobile phase consisted of acetonitrile-water $(50: 50, \mathrm{v} / \mathrm{v})$ for $9 \mathrm{~min}$ and $100 \%$ acetonitrile for $3.5 \mathrm{~min}$.

\section{Hydrocarbon index}

The extraction of total petroleum hydrocarbons (TPHs) was performed by a ASE technology (Dionex ASE 350), allowing a solid/liquid extraction at $100^{\circ} \mathrm{C}$ under a pressure of $1500 \mathrm{psi}$, with a solvent mixture of $n$-hexane-acetone $(50: 50, \mathrm{v} / \mathrm{v})$. The recovered extract was washed with an aqueous solution of hydrated magnesium sulfate to remove acetone and then cleaned up on a Florisil column (6 mm diameter, $6 \mathrm{~cm} \mathrm{long}$ ). The eluate was then concentrated with a Syncore Analyst Evaporator to $0.5 \mathrm{ml}$ to be used for analysis by gas chromatography (GC-FID) using a Column VF-5ht $15 \mathrm{~m} \times 0.25$ $\mathrm{mm} \times 0.10 \mu \mathrm{m}$ with a "splitless" injection technique $(30 \mathrm{sec})$ and a pulse injection (10 psi for $1 \mathrm{~min}$ ). The analyses were conducted under the following conditions: injection temperature, $300^{\circ} \mathrm{C}$; injection volume, $1 \mu \mathrm{l}$; carrier gas, helium; oven temperature program, $40^{\circ} \mathrm{C}$ for $5 \mathrm{~min}$ to $300^{\circ} \mathrm{C}$ and $300{ }^{\circ} \mathrm{C}$ for $5 \mathrm{~min}$; flame ionization detector temperature, $330{ }^{\circ} \mathrm{C}$. The following fractionation was performed: (C10-C12), (C12$\mathrm{C} 16),(\mathrm{C} 16-\mathrm{C} 21),(\mathrm{C} 21-\mathrm{C} 35)$ and (C35-C40). The limits of integration were placed at the corresponding retention times of $n$-alkanes $(\mathrm{C} 12, \mathrm{C} 16, \mathrm{C} 21$ and C35), areas of each fraction were measured and the calculation based on the total area $\mathrm{C} 10-\mathrm{C} 40$.

\section{Plant growth and root growth analysis}

Pea seeds (Pisum sativum L.) "Kelvedon wonder" were surface-sterilized with $0.1 \%$ sodium hypochlorite $(\mathrm{NaClO})$ for $10 \mathrm{~min}$, rinsed and soaked in distilled water at room temperature for $12 \mathrm{~h}$. The seeds were germinated on water-imbibed paper in sealed plastic dishes. After three days, pea seedlings were transplanted into plastic containers containing $250 \mathrm{~g}$ of a mixture of peat and sand, polluted or control, (80:20, w/w). Plants were cultivated for 21 days under controlled conditions in a growth chamber with a $16 \mathrm{~h}$ 
light $(90 \mu \mathrm{E})$ and $8 \mathrm{~h}$ dark cycle at a constant temperature of $25{ }^{\circ} \mathrm{C}$ and relative air humidity of $60 \%$, watered by pure water according to usable water to field capacity calculated in gram of water per gram of sandy soil and after wards, every other day till the end of the experiment. The dry weight of roots, the number of lateral roots and the length of the primary root of plants were measured after 21 days of culture.

\section{Hydrogen peroxide detection}

Hydrogen peroxide was detected by a colorimetric method using 3,3 diaminobenzidine (DAB). DAB is taken up by living plant tissue and can be used to show $\mathrm{H}_{2} \mathrm{O}_{2}$ production when peroxidase activity is present (Thordal- Christensen et al., 1997). The root apices (excised $1 \mathrm{~cm}$ from the tip) were immersed in the dark for $12 \mathrm{~h}$ in a $1 \mathrm{mg} \cdot \mathrm{ml}^{-1}$ DAB solution in water at room temperature with gentle stirring. Hydrogen peroxide causes a redox polymerization with DAB molecule giving a stable brown precipitate at the reaction site.

\section{Superoxide anion detection}

The superoxide anion $\mathrm{O}_{2}^{-}$is detected by colorimetric method using nitrobluetetrazolium (NBT) (Rao and Davis, 1999). Superoxide radicals reduce NBT to form a stable formazan blue blue-indigo (Beyer and Fridovich, 1987). Root apices (5 $\mathrm{cm}$ from the tip) were immersed in a $0.5 \mathrm{mg} / \mathrm{ml} \mathrm{NBT}$ solution in $0.1 \mathrm{M}$ sodium phosphate buffer $\mathrm{pH}$ (7.8) for $1 \mathrm{~h}$ at room temperature and in the dark. The root samples were rinsed in boiling $96^{\circ}$ ethanol for 10 minutes. The root samples were stored in a glycerol-ethanol solution $(1: 4, \mathrm{v} / \mathrm{v})$ until photographs were taken under a light microscope.

\section{Determination of lipid peroxidation}

Lipid peroxidation was determined as the amount of malondialdehyde (MDA) in roots. MDA is a thiobarbituric acid reactive substance (TBARS), which was measured according to Achary et al (2008). Root fragments were homogenized in $1.5 \mathrm{ml}$ of reaction mixture containing $20 \%(\mathrm{w} / \mathrm{w})$ trichloroacetic acid and $0.5 \%$ (W/V) thiobarbituric acid, heated at $95{ }^{\circ} \mathrm{C}$ for $30 \mathrm{~min}$, cooled on ice then centrifuged $10 \mathrm{~min}$ at $13000 \mathrm{~g}$. The absorbance of the supernatant at $532 \mathrm{~nm}$ and $600 \mathrm{~nm}$ was measured. The nonspecific absorbance at $600 \mathrm{~nm}$ was subtracted from that at $532 \mathrm{~nm}$. The concentration of MDA was calculated using an extinction coefficient of $155 \mathrm{mM} \mathrm{cm}^{-1}$.

\section{Extraction of enzymes}

Plant roots $(100 \mathrm{mg})$ were homogenized in $2 \mathrm{~mL}$ of $50 \mathrm{mM}$ potassium phosphate buffer ( $\mathrm{pH}$ 7.0) containing $1 \mathrm{mM}$ ethylene diamine tetraacetic acid (EDTA) and a small amount of polyvinylpyrrolidone (PVP). The homogenate was centrifuged at $4{ }^{\circ} \mathrm{C}$ for 20 $\min$ at $12000 \times g$. The resulting supernatant was used to measure peroxidase and superoxide dismutase activities. An aliquot of $0.1 \mathrm{ml}$ was used to determine the protein content as per the method of Bradford (1976) using bovine serum albumin as standard.

\section{Peroxidase activity}

The peroxidase (POD) reaction solution $(3 \mathrm{ml})$ contained $50 \mathrm{mM}$ phosphate buffer ( $\mathrm{pH} \mathrm{5),} 20 \mathrm{mM}$ guaiacol, $40 \mathrm{mM} \mathrm{H}_{2} \mathrm{O}_{2}$ and $0.1 \mathrm{ml}$ of enzyme extract. Changes in 
absorbance of the reaction solution at $470 \mathrm{~nm}$ were determined every $20 \mathrm{~s}$. One unit of POD activity was defined as an absorbance change of 0.01 absorbance units per min. The enzyme activities were expressed relative to the protein content (Chance and Maehly, 1955).

\section{Superoxide dismutase activity}

Superoxide dismutase (SOD) activity was assayed by measuring the ability to inhibit the photochemical reduction of nitro blue tetrazolium (NBT). The 3-ml reaction solution contained $50 \mu \mathrm{M}$ NBT, $1.3 \mu \mathrm{M}$ riboflavin, $13 \mathrm{mM}$ methionine, $75 \mathrm{nM}$ EDTA, $50 \mathrm{mM}$ phosphate buffer ( $\mathrm{pH} 7.8)$ and 20-50 $\mu$ l of enzyme extract. The test tubes containing the reaction solution were irradiated by light. One unit of SOD activity was defined as the amount of enzyme required to cause $50 \%$ inhibition of the reduction rate of NBT as monitored by absorbance at $560 \mathrm{~nm}$ (Giannopolitis and Ries, 1977).

\section{Anatomical studies}

To investigate the internal structure of pea roots, we made cross sections at two similar positions relative to the root tip (Figure. 1) to avoid the oscillation zone, a region of the spatial and temporal definition of lateral roots pre-branching sites (Jung and McCouch, 2013), and to have more differentiated tissues. Six plants were randomly selected from both soils. Roots were fixed in FAA $\left(95^{\circ}\right.$ ethanol - 35\% formaldehyde acetic acid, 2:17:1, v/v) for $24 \mathrm{~h}$, washed with distilled water several times then progressively dehydrated through an ethanol series up to $70^{\circ}$ ethanol. For epifluorescence observations fresh samples were used. Fixed and fresh samples were cut with a vibratome in order to obtain 60-micrometer transverse sections. Staining with iodine green carmine was carried out as described in Locquin and Langeron (1978). Briefly, sections were placed for 10 to $20 \mathrm{~min}$ in sodium hypochlorite, then washed thoroughly with water, incubated in dilute acetic acid and stained with carmine-green iodine. After staining sections were washed with water. Microphotographs were taken by using a Zeiss Axioskop microscope equipped with an AxioCam camera MR (Zeiss) using $\times 50$ and $\times 100$ magnification objective lenses and the images were processed and archived with AxioVision software (Zeiss).

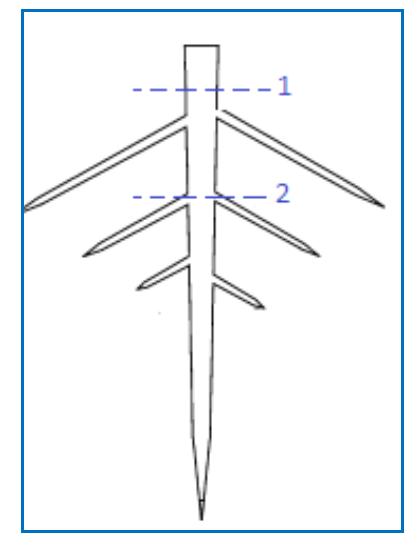

Figure 1. Diagram of root scheme with location of sections used for anatomical studies

To visualize lignified cells, sections were examined by using a digital imaging station comprising a motorized Zeiss Axio Imager Z1 microscope equipped with a light 
sensing device with automated color correction (Apotome, Zeiss). This system allows the observation of epifluorescence with a HBO mercury vapor light source type, which provides excitation light in the 340-700nm range.

Lignin autofluorescence was detected using the Zeiss HE DAPI filter set 49 (excitation, $3656 \mathrm{~nm}$; emission, 420-470 nm). Digital fluorescence images were generated by an AxioCam MR Camera (Zeiss), using $\times 50$ and $\times 100$ magnification objective lenses. Images were processed and archived with AxioVision software (Zeiss).

\section{Statistical analysis}

All data presented are the mean values of five replicates \pm standard deviation (SD). Statistical analysis was carried out by ANOVA analysis at a 5\%, $1 \%$ and $0.1 \%$ significance level, using the statistical software package STATISTICA version 8.0.

\section{Results}

\section{Soil analysis and hydrocarbon index}

Samples of sandy soil were collected at a disused oil-drilling quagmire in southern Algeria was analyzed by GC-FID and UPLC. Control soil samples, collected from a non-industrial site $2 \mathrm{~km}$ away, had a similar sandy texture. Analysis showed presence of molecules of low and high molar mass. Gas phase chromatography showed the presence of $18 \mathrm{~g}$ of total petroleum hydrocarbon (TPH) per $\mathrm{kg}$ of polluted soil (Figure 2A). Fractionation of these hydrocarbons (Fig. $2 A, C$ ) showed that they are mainly a mixture of C12-C21 molecules (Fig. 2A). No hydrocarbon was detected in control soil (Fig. 2B). Polyaromatic hydrocarbon (PAH) content of polluted soil analysis by UPLC showed the presence of fluorene $\left(15.3 \mu \mathrm{g} \mathrm{kg}^{-1}\right)$, phenanthrene $\left(781.4 \mu \mathrm{g} \mathrm{kg}^{-1}\right)$, fluorenthene $(30.9 \mu \mathrm{g}$ $\left.\mathrm{kg}^{-1}\right)$ and pyrene $\left(282.5 \mu \mathrm{g} \mathrm{kg}^{-1}\right)$. Concentrations of other PAHs were below the detectable values.

Analysis showed an increase in soil moisture, total organic carbon, phosphorus and nitrate in polluted soil, but no significant differences for nitrite, $\mathrm{pH}$ and conductivity with control soil.

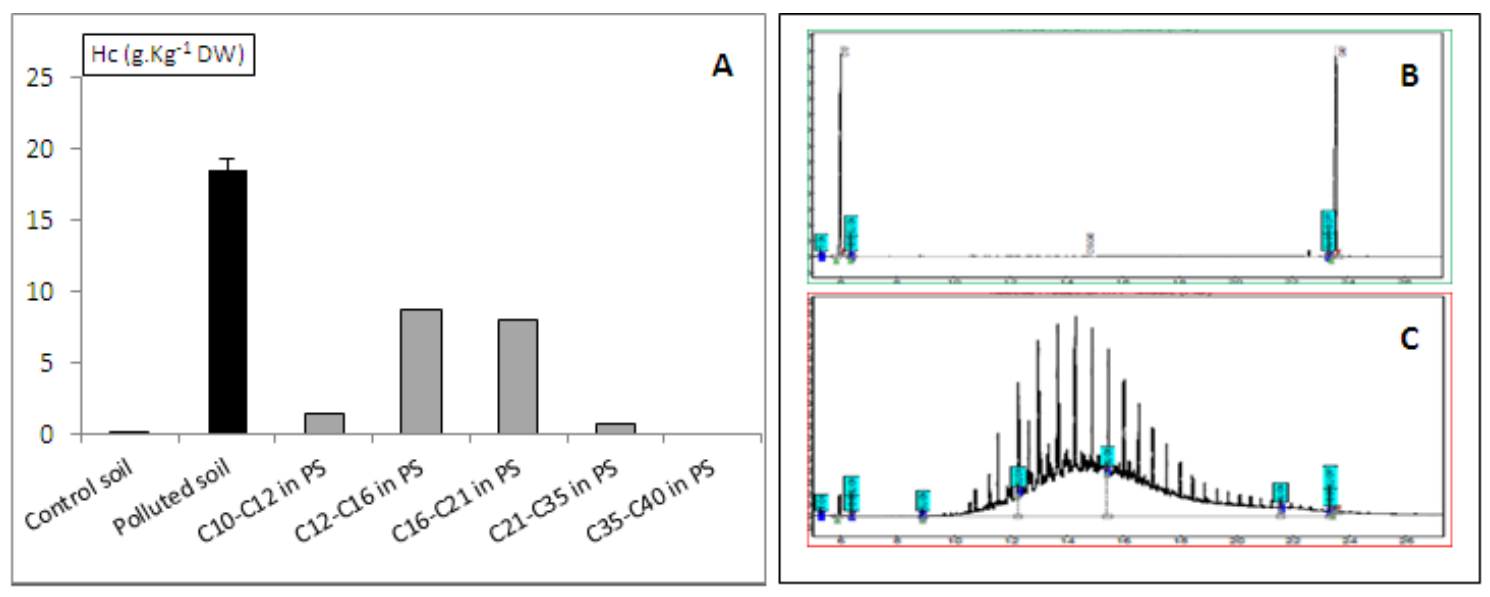

Figure 2. (A) Hydrocarbon index in control (CS) and polluted soil (PS) and fractionation of hydrocarbons in (PS). Chromatogram of hydrocarbons from $(B)$ control soil and $(C)$ polluted soil. 


\section{Hydrocarbon pollution affects root growth}

To investigate the possible deleterious effect of polluted sand on plant growth, Pisum sativum L. (pea) plants were grown in laboratory conditions in both control and hydrocarbons contaminated soil. We noted that 21-day-old pea seedlings on polluted soil developed all aerial organs like the control but were shorter (Figure 3A). To assess the effect of pollutants in direct contact with roots, we uprooted the plants and measured primary and lateral root lengths and number (Fig. 3 B, C). Primary root length is $37 \%$ shorter in pea plants grown in polluted soil compared with those of controls (Fig. 3B). Root architecture is a plastic phenotype being characteristic of individual species but also determined by the growth environment. Pea plants growing on polluted soil had $36 \%$ fewer lateral roots per plant (Fig. 3C). There was no significant difference in total root mass (including primary and lateral roots) in seedlings grown in both type of soil (Fig. 3D). In contrast, the dry weight of lateral roots from plants grown in polluted soil was $35 \%$ higher than that of lateral roots in control soil (Fig. 3D).
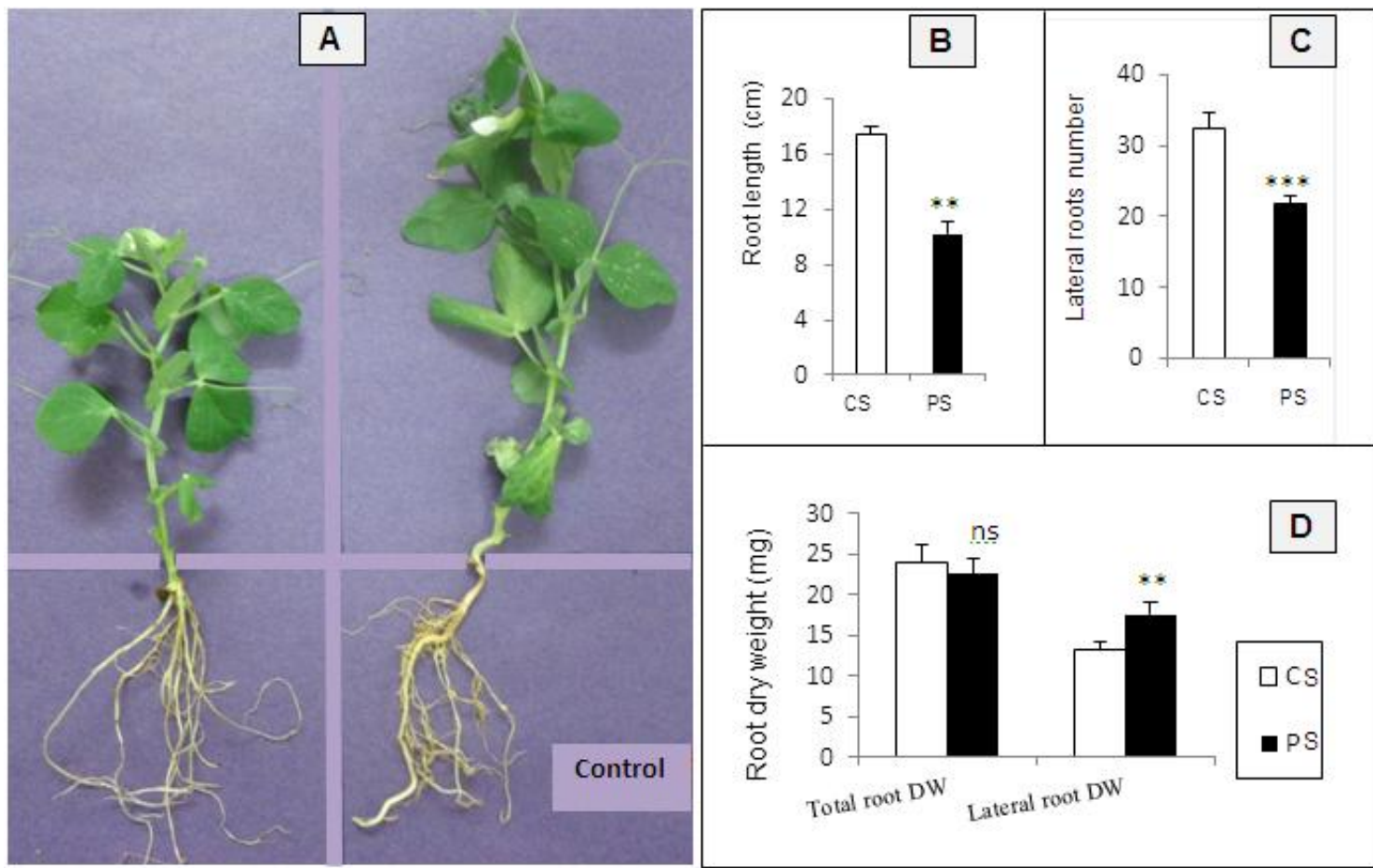

Figure 3. (A) Morphology, (B) primary root length, (C) number of lateral roots and (D) dry weight of roots of pea seedlings grown in control (CS) and hydrocarbon polluted soils $(P S)$.Values showing means quares from analysis of variance of data for each variable; ** and ***: significant at 0.01 and 0.001 level respectively, $n$ s: not significant

\section{Effect of hydrocarbons on oxidative stress in pea roots}

The adverse effects of polluted soil on primary root length and lateral root initiation and mass might be caused by direct chemical effects of the molecules or indirectly by affecting the physiology of plants, for example, by causing stress. We tested whether the polluted soil causes stress in pea roots by measuring known oxidative stress molecules. 
Reactive oxygen species (ROS) such as the superoxide radical $\mathrm{O}_{2}{ }^{-}$can be formed during stress by NADPH-oxidase enzymes or by the reaction of electron transfer chains, enzymes or metals with oxygen. NBT staining of pea seedlings grown in hydrocarbon polluted soil revealed that a large amount of superoxide accumulated along the length of the root from about $5 \mathrm{~cm}$ from the root tip to the tip itself (Figure $4 \mathrm{~A}, \mathrm{~B}$ ). Hydrogen peroxide $\left(\mathrm{H}_{2} \mathrm{O}_{2}\right)$, another ROS, is also formed in stressed tissues, either from superoxide metabolism or directly from water. $\mathrm{H}_{2} \mathrm{O}_{2}$ was revealed by DAB staining in roots (Fig. 4 $C, D$ ). The intensity of brown spots in stained roots indicates the relative accumulation of $\mathrm{H}_{2} \mathrm{O}_{2}$. In pea roots exposed to hydrocarbons the brown coloration is concentrated at the end of root tips (Fig. $4 \mathrm{D}$ ). In contrast in control roots, almost no staining with NBT or DAB was observed (Fig. 4. A, C). Membrane lipid peroxidation is often a consequence of damage that occurs when cells are exposed to superoxide or other ROS. Malondialdehyde (MDA) is an indicator of lipid peroxidation and MDA content reflects oxidative stress. The MDA content of roots grown in hydrocarbon-polluted soil was $22.7 \%$ higher than in control roots (Fig. 4 E).

Another indicator of oxidative stress is the activity of detoxification enzymes such as superoxide dismutase (SOD) and peroxidase (POD) that are able to catabolise superoxide and hydrogen peroxide respectively. Both SOD and POD activities were over $40 \%$ higher in roots from plants growing in polluted soil than in control roots (Fig. 4 F, G).

Our study reveals that pea roots growing on soil polluted with PAHs display symptoms of oxidative stress because both superoxide and hydrogen peroxide are produced and accumulate and detoxification enzymes are expressed suggesting a sustained physiological response to polluted conditions.
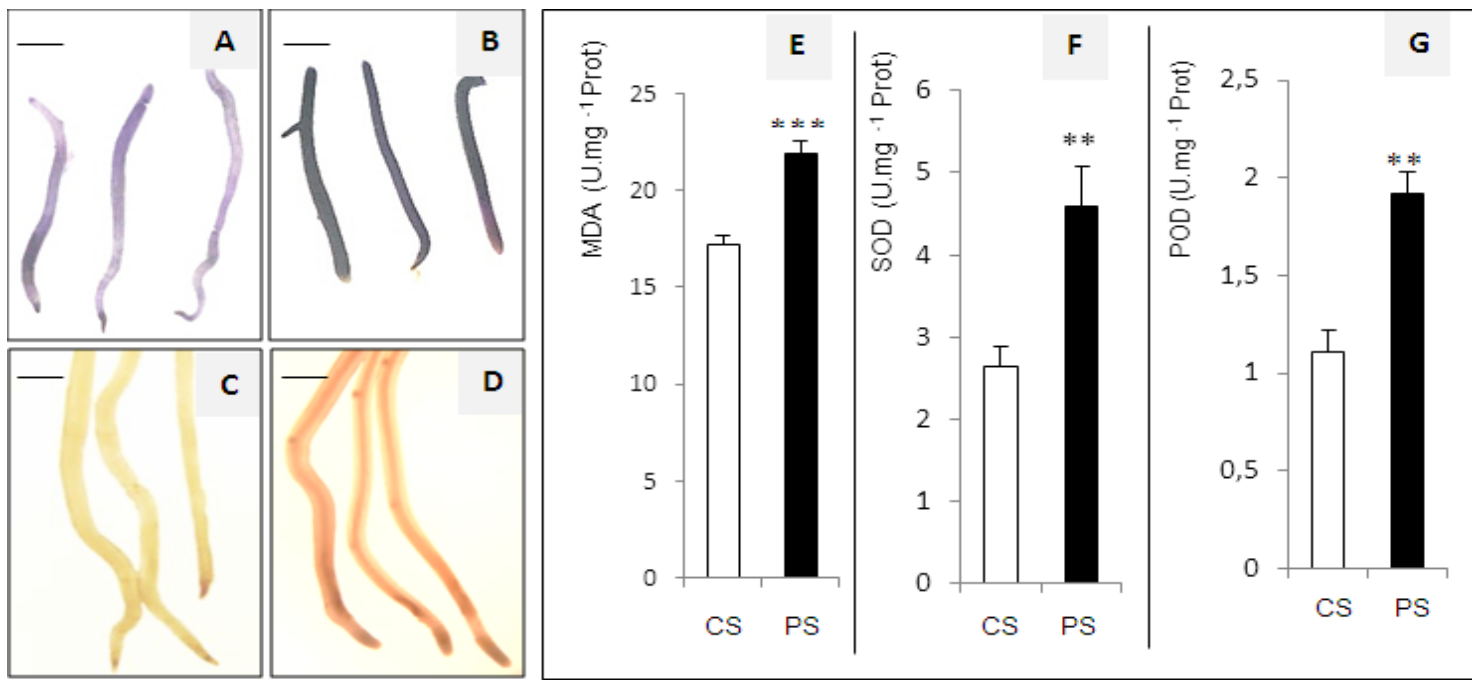

Figure 4. NBT (A-B) and DAB staining $(C-D)$ detect superoxide and hydrogen peroxide respectively. Pea root tips grown in control $(A, C)$ or polluted soil $(B, D)$. Scale bar $=1 \mathrm{~cm}$. $M D A(E), S O D(F)$ and $P O D(G)$ activities in pea roots grown for 21 days in control $(C S)$ and hydrocarbon polluted soil (PS). Values are significantly different at $0.01 * *$ and $0.001 * * *$, respectively.

\section{Anatomical studies}

Our study suggests that the presence of hydrocarbons in soil affected many aspects of root growth. The overall root anatomy is similar in both polluted and control plant 
samples with cortex cells similar in size both types of roots samples. However there was a slight flattening of cortex cells in the primary roots that had been exposed to polluted soil (Figure 5 A, E). Lateral root initiation was observed in both samples (Fig. 5 B, F).

When xylem vessels were viewed more closely (Fig. $5 C, G$ ), evidence of the centripetal differentiation of three primary xylem vessels was clearly observed in the primary root in both samples. However secondary xylem differentiation appears retarded in plants grown in the presence of hydrocarbons as much as less secondary xylem is present compared to control (Fig. 5 C, G).

Assuming the presence of hydrocarbons in soil caused a delay in the differentiation of secondary xylem, we looked for other signs that differentiation was affected. Lignin fluorescence was observed in cell walls under UV-fluorescent microscopy. Lignified xylem vessels are noticeably smaller in plants growing in polluted soil compared to control plants (Fig. $5 \mathrm{D}, \mathrm{H}$ ). Most surprisingly in plants grown in polluted soil we observed a two-cell layered endodermis possibly adjacent to suberized cells (Figure 5 $H$, yellow circle). Roots grown in hydrocarbon-polluted soil therefore have unusual xylem and endodermis differentiation.

A

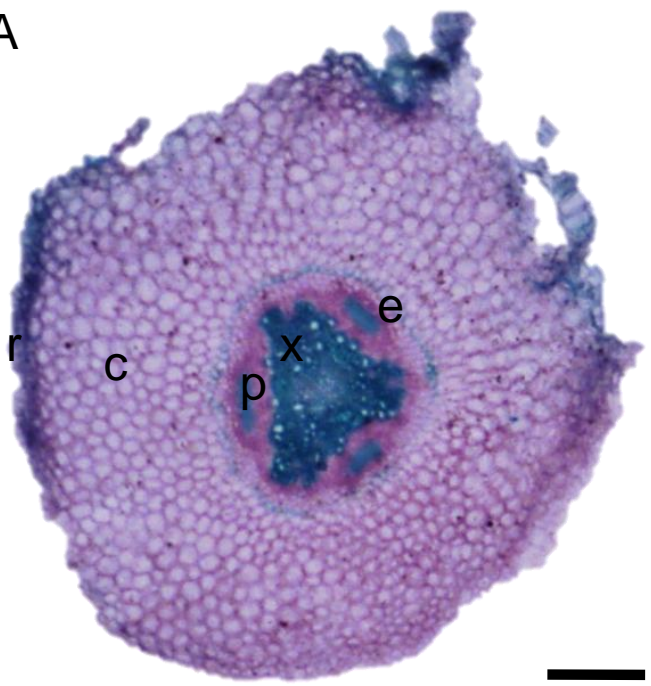

B

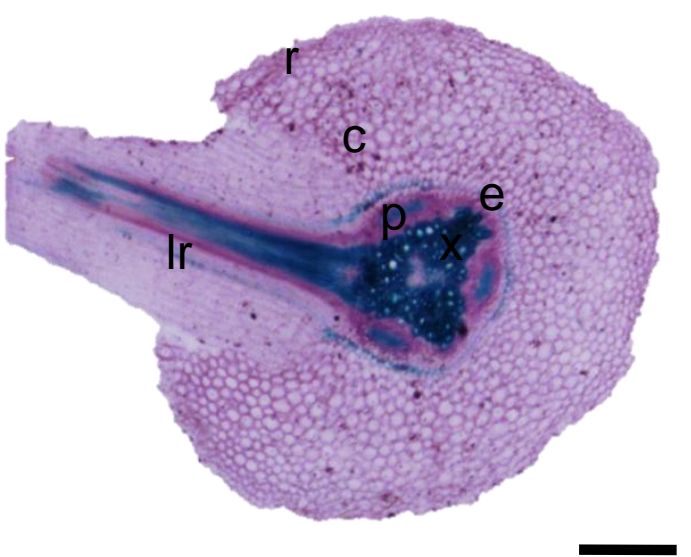

$E$

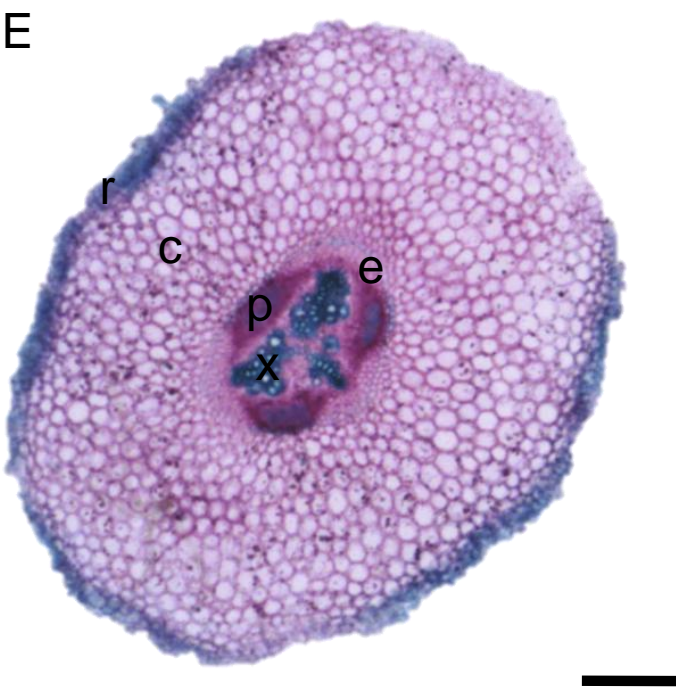

$\mathrm{F}$

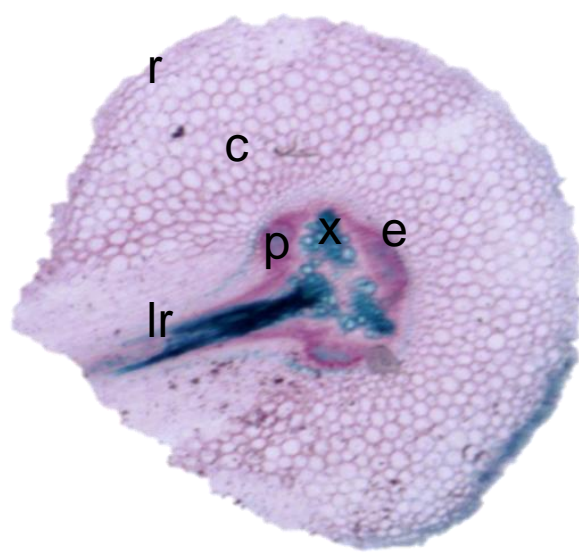



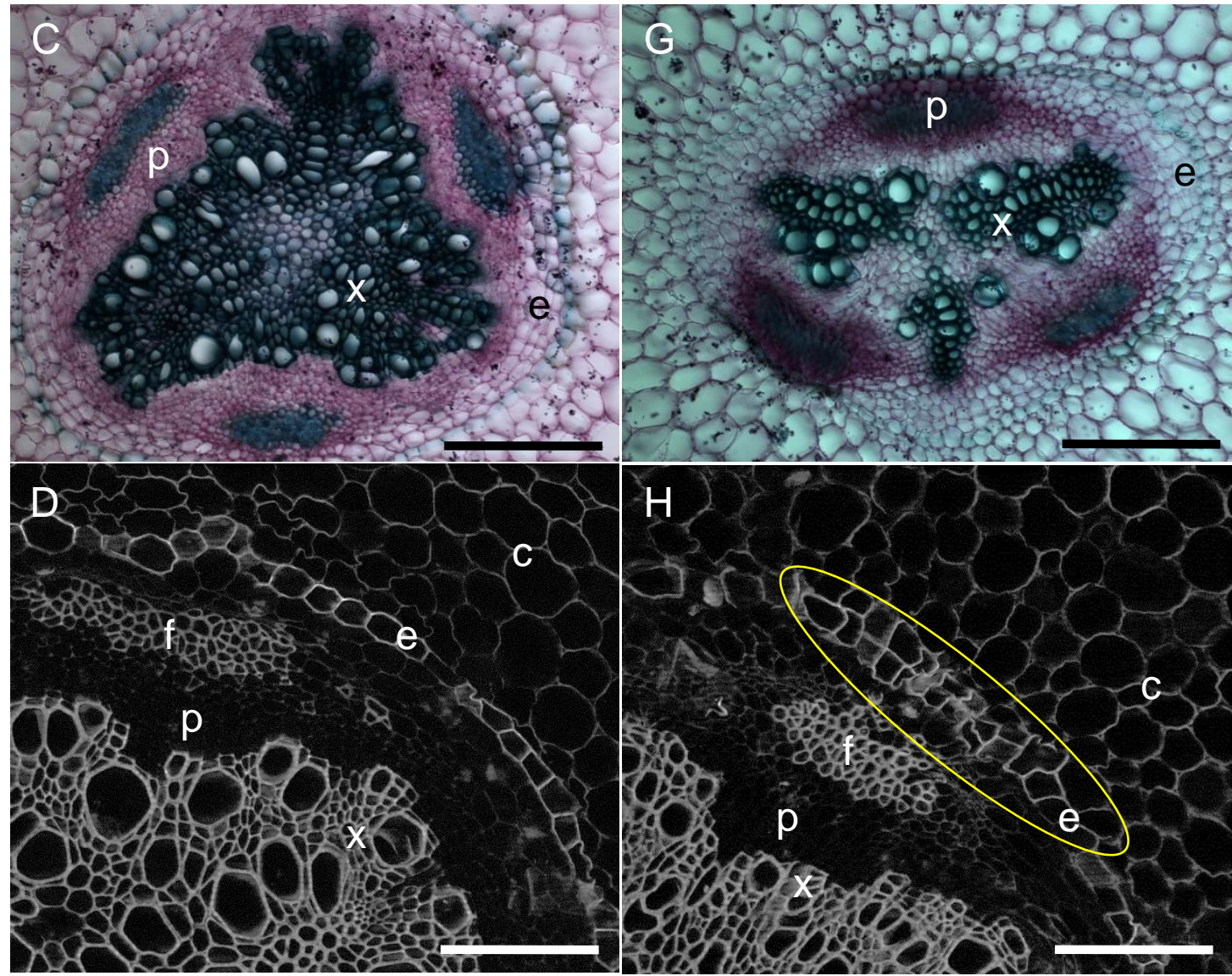

Figure 5. Transverse sections of pea roots grown in control $(A, B, C, D)$ and hydrocarbon polluted soil $(E, F, G, H)$, observed by light microscopy $(A, B, C, E, F, G)$ and by fluorescence microscopy $(D, H)$. c, cortex; e, endodermis; f, fibers; lr, lateral root; $p$, phloem; $r$, rhizodermis; $x$, xylem. Scale bar, $500 \mu m$.

\section{Discussion}

\section{Hydrocarbon in soil}

Diesel fuel, on entering the terrestrial environment, will spread and seep into the soil. Michel et al (2002), state that petroleum constitutes a pollutant that can persist in the environment for a long period until the vegetation recovers completely, and its persistence can be explained by the slow biodegradation of hydrocarbons. The downward migration of diesel fuel through the soil profile however is limited due to the physical properties of the fuel (Adam and Duncan, 1999). Presence of total petrolium hydrocarbon (TPHS) in soil can cause damage in short and long term for the plant. The immediate toxic effect tends to be caused mainly by molecules of low molar mass that are quickly degraded. The chronic toxic effects, however, are due to molecules of high molar mass, generally aromatic, that present lower toxicity, but are persistent, causing a longer lasting effect (Spies et al., 1996).

\section{Root morphology is disturbed in pea plants grown in polluted soil}

Root growth and development are controlled by endogenous cues such as phytohormones (Casimiro et al., 2001). However exogenous factors such as water, 
salinity, nutrients or the presence of toxic metals have a considerable impact on the final root structure (Arduini et al., 1994). Many plant species are sensitive to petroleum contaminants (Huang et al., 2004). Hydrocarbons in the soil may prevent uptake of nutrients that are less mobile in contaminated soils (Atuanya, 1987). Water and nutrient absorption can also be limited by hydrophobic molecules, which can form a layer over the root when in excess in the soil (Quinones-Aquilar et al., 2003). Inhibition of plant growth parameters (germination, plant length, and biomass) can be caused by toxic compounds of petroleum hydrocarbons (Bossert and Bartha, 1985), such as low molecular weight hydrocarbons.We observed both inhibition of primary root growth and fewer lateral roots in pea plants growing on polluted soils. These results are reminiscent of the known inhibition of lateral root formation and initiation of root primordia by PAHs (Alkio et al., 2005; Baldyga et al., 2005).

There was no significant difference in the dry weight of total roots (primary and lateral roots). Interestingly pea plants grown on oil-contaminated fields also had a similar root dry weight as control plants after three weeks of growth (Xu and Johnson, 1995), although in older plants root weight was lower in polluted plants than in controls (Xu and Johnson., 1995). Generally, lateral roots appear thicker in the polluted samples.

\section{Hydrocarbon pollution is associated with oxidative stress in pea plants}

Many environmental stresses induce ROS production (Apel and Hirt, 2004). Their reaction with other molecules such as proteins or nucleic acids is often deleterious to the cells. Lipids when peroxidised lead to MDA accumulation and altered cell integrity (Apel and Hirt, 2004). ROS and ROS-detoxifying enzymes are more abundant in roots from pea plants grown in polluted soil. The presence of PAH in polluted soil might be directly responsible for ROS production, as it is generally observed that PAHs induce ROS production in plants, as seen with phenanthrene (Alkio et al., 2005) and Nheterocyclic PAHs (Paskova et al., 2006).

The observed increase in MDA in roots grown in polluted soil is suggestive of oxidative damage as a consequence of ROS accumulation. It indicates that hydrocarbon-induced stress alters biological membranes and affects cellular integrity. Phenanthrene alone can induce ROS generation, MDA production, and oxidative stress (Liu et al., 2009).

ROS abundance depends on rates of ROS generation and rate of ROS degradation and scavenging/neutralizing by antioxidants whether through enzymatic and/or nonenzymatic mechanisms (Amor et al., 2005). Plants have numerous detoxification mechanisms, such as glutathione S-transferases, POD, catalases, and SOD and nonenzymatic molecules like glutathione (Won et al., 2012). SOD activity and proteins increase in response to stress in plants (Shalini and Dubey, 2003; Song et al., 2006).

Detoxifying enzyme activity or abundance is induced by hydrocarbons, such as diethyl phthalate (Cheng and Cheng, 2012) and phenanthrene (Song et al., 2006) in greater duckweed Spirodela polyrhiza. We found that ROS detoxifying activities SOD and POD increased in roots of hydrocarbon-polluted pea plants suggesting that pea plants respond to environmental stress by producing detoxifying enzymes. This finding is broadly consistent with other abiotic stress responses, which quench excess ROS through enzymatic reduction to water, and oxidize electron-rich buffers such as ascorbate and glutathione (Apel and Hirt, 2004). However here not all of the stressinduced ROS are eliminated, leading to MDA accumulation. 


\section{Anatomy}

The results of this study support the idea that the presence of hydrocarbons in soil has affected not only the morphology and root development, but also their anatomical structure. Indeed we show that roots grown in polluted soils are delayed in xylem differentiation and have an additional cell layer in the endodermis.

Our results are in agreement with Kummerova et al. (2013), who showed that in pea and maize roots, the proportion of xylem vessels in the stele decreased when exposed to fluoranthene. Pea roots with less xylem in response to hydrocarbons in soil may be interpreted as an adaptation to minimize absorption of polluted water, because vessel number and diameter influence the amount of water flowing. Hernandez-Ortega et al. (2014) reported that values of hydraulic parameters diminished, but the loss of hydraulic conductivity was significantly enhanced as the diesel concentration increased. In addition fluoranthene exposure triggers changes in the cell morphology of other organs and tissues including the root tip, root cap, apical meristem and elongation zone (Kummerova et al., 2013). Similar abnormal development patterns of xylem have been also described in cotton grown in presence of high salinity (Reinhardt and Rost, 1995). Thus the xylem tissue seems to be particularly sensitive to external abiotic pollutant.

A single layer of endodermis in plants is defined by an evolutionarily conserved mechanism, where the SCARECROW (SCR) protein associated with the mobile SHORT-ROOT (SHR) protein delimits endoderm and pericycle founder cells around the quiescent center at the root tip (Cui et al., 2007). In our study, pea roots grown in polluted soils showed an additional division in endodermis. Observing a supernumerary cell division and cell differentiation in the developing root suggests that hydrocarbons modify the existing differentiation pattern. The endodermis is the innermost layer of the cortex and is characterized by the formation of Casparian bands in the anticlinal walls of its cells (Enstone et al., 2003). An extra cell layer might contribute to limiting exchanges between the cortex cells and the stele tissues reducing the import of hydrocarbons in the xylem flux. This might be another anatomical adaptation to pollutants like Casparian band and suberin lamellae thickening, increased suberization and lignification of endodermis cells (Zelko and Lux, 2004; Vance et al., 1980; Kalaji and Pietkiewicz, 1993; Shannon et al., 1994; Schreiber et al., 1999).

Overall hydrocarbon residues found in sand samples extracted from the quagmire site profoundly modify plant growth and root architecture. ROS production and ROS detoxifying enzymes are induced in pea, most likely a consequence of physiological stress. We found that morphological and anatomical changes in pea roots exposed to anthropogenic pollution might be an adaptation to abiotic stress limiting the impact of the pollutant hydrocarbons on roots.

Acknowledgements. We thank members of the Laboratory of ISSeP in Colfontaine, Belgium and of the UPMC-Paris Laboratory of Plant Adaptation to Environmental Constraints for their help and technical assistance in soil hydrocarbon analysis and anatomical studies.

\section{REFERENCES}

[1] Achary, V. M. M., Jena, S., Panda, K. K., Panda, B. B. (2008): Aluminum induced oxidative stress and DNA damage in root cells of Allium cepa L. - Ecotoxicol and Environmental Safety 70: 300-310. 
[2] Achuba, F.I. (2006): The effect of sublethal concentrations of crude oil on the growth and metabolism of Cowpea (Vigna unguiculata) seedlings. - The Environmentalist 26: 17-20.

[3] Adam, G., Duncan, H. (1999): Effect of diesel fuel on growth of selected plant species. Environmental Geochemistry and Health 21: 353- 357.

[4] Alkio, M., Tabuchi, T. M., Wang, X., Colon-Carmona, A. (2005): Stress responses to polycyclic aromatic hydrocarbons in Arabidopsis include growth inhibition and hypersensitive responses-like symptoms. - Journal of Experimental Botany 56 (421): 2983-2994.

[5] Amor, N. B., Hamed, K. B., Debez, A., Grignon, C., Abdelly, C. (2005): Physiological and antioxidant responses of the perennial halophyte Crithmum maritimum to salinity. Plant Science 168: 889-899.

[6] Anoliefo, G. O. (1991): Forcados blend crude oil effect in respiration, metabolism, elemental composition and growth of Citrullus vulgaris (Schrad). Ph.D. Thesis, Benin.

[7] Apel, K., Hirt, H. (2004): Reactive oxygen species: metabolism, oxidative stress, and signal transduction. - Annual Review of Plant Biology 55 (1): 373-399.

[8] Arduini, S., Godbold, D. L., Onnis, A. (1994): Cadmium and coper change root growth and morphology of Pinus pinea and Pinus pinaster seedlings. - Plant Physiology 92: 675680 .

[9] Atuanya, E.J. (1987): Effect of oil pollution on physical and chemical properties of soil, a case study of waste oil contaminated delta soil in Bendel State. Nigeria. - Journal of Applied Science 55: 155-176.

[10] Baldygà, B., Weiczorek, J., Smoczynski, S., Weiczorek, Z., Smoczinska, K. (2005): Pea plant response to Anthracene present in soil. - Polish Journal of Environmental Studies 14: 397-401.

[11] Beyer, W. F., Fridovich, I. Jr. (1987): Assaying for superoxide dismutase activity: some large consequences of minor changes in conditions. - Analytical Biochemistry 161: 559566.

[12] Bossert, I., Bartha, R. (1985): Plant growth in soils with a history of oily sludge disposal. - Soil Science 140: 75-77.

[13] Bradford, M. M. 1976. A rapid and sensitive method for the quantification of microgram quantities of protein utilizing the principle of protein-dye binding. - Analytical Biochemistry 72: 248-254.

[14] Casimiro, L., Marchant, A., Bhalerao, R.P., Beeckman, T., Dhooge, S., Swarup, R., Graham, N., Inzé, D., Sandberg, G., Casero, P.J., Bennett, M. (2001): Auxin transport promoters Arabidopsis lateral root initiation. - Plant Cell 13: 843-852.

[15] Chance, M., Maehly, A.C. (1955): Assay of catalases and peroxidases. - Methods Enzymology 2: 764-817.

[16] Cheng, L-J., Cheng, T-S. (2012): Oxidative effects and metabolic changes following exposure of greater duckweed (Spirodela polyrhiza) to diethyl phthalate. - Aquatic Toxicology 109: 166-175.

[17] Cui, H., Levesque, M. P., Vernoux, T. (2007): An evolutionarily conserved mechanism delimiting SHR movement defines a single layer of endodermis in plants. - Science 316: 421-425.

[18] Culbertson, J.B., Valiela, I., Pickart, M., Peacock, E. E., Reddy, C. M. (2008): Longterm consequences of residual petroleum on salt marsh grass. - Journal of Applied Ecology 45: 1284-1292.

[19] De Jong, E. (1980). Effect of a crude oil spill on cereals. - Environmental Pollution 22: 187-307.

[20] Enstone, D. E., Peterson, C. A., Ma, F. (2003): Root Endodermis and Exodermis: Structure, Function, and Responses to the Environment. - Journal of Plant Growth Regulation 21: 335-351.

[21] Gao, Y. Z., Zhu, L. Z. (2004): Plant uptake, accumulation and translocation of phenanthrene and pyrene in soils. - Chemosphere 55: 1169-1178. 
[22] Giannopolitis, C. N., Ries, S. K. (1977): Superoxide dismutases: Occurrence in higher plants. - Plant Physiology 59: 309-314.

[23] Gill, L. S., Nyawuame, H. G. K., Ehikhametalor, A. O. (1992). Effect of crude oil on the growth and anatomical features of Chromolaena odorata L. - Chromolaena odorata Newsletter 6:1-6.

[24] Hernandez-Ortega, H. A., Quintanar-Isaias, P.A., Jaramillo-Pérez, A. T., Alancon, A., Ferrera-Cerato, R., Lazzarini Lechuga, R. (2014): Diesel effects on root hydraulic conductivity and morphological changes of the vascular cylinder in Medicago sativa. Environmental and Experimental Botany 105:1-9.

[25] Huang, X. D., El-Alawi, Y., Penrose, D. M., Glick, B. R., Greenberg, B. M. (2004): A multi-process phytoremediation system for removal of polycyclic aromatic hydrocarbons from contaminated soils. - Environmental Pollution 130: 465-476.

[26] Jung, J. K. H., McCouch, S. (2013): Getting to the root of it: genetic and hormonal control of root architecture. - Frontiers in Plant Science 4: 186.

[27] Kalaji, M.H.,Pietkiewicz, S. (1993): Salinity effects on plant growth and other physiological processes. - Acta Physiologiae Plantarum 15: 89-124.

[28] Korte, F., Kvesitadze, G., Ugrekhelidze, D., Gordeziani, M., Khatisashvili, G., Buadze, O., Zaalishvili, G., Coulston, F. (2000): Organic toxicants and plants. - Ecotoxicology and Environmental Safety 47: 1-26.

[29] Kummerová, M., Zezulka, S., Váňová, L., Fišerová, H. (2012): Effect of organic pollutant treatment on the growth of pea and maize seedlings. - Central European Journal of Biology 7(1) : 159-166.

[30] Kummerova, M., Zezulka, S., Babula, P., Vànovà, L. (2013): Root response in Pisum sativum and Zea mays under fluoranthene stress: Morphological and anatomical traits. Chemosphere 90: 665-673.

[31] Li, K. Y., Kane, A. J., Wang, J. J., Cawley, W. A. (1993): Measurement of biodegradation rate constants of a water extract from petroleum contaminated soil. Waste Manage 13: 245-251.

[32] Liu, H., Weisman, D., Ye, Y.B., Cui, B., Huang, Y. H., Colon-Carmona, A., Wang, Z. H. (2009): An oxidative stress response to polycyclic aromatic hydrocarbon exposure is rapid and complex in Arabidopsis thaliana. - Plant Science 176: 375-382.

[33] Locquin, M., Langeron, M. (1978): Manuel de microscopie. Ed. Masson. France.

[34] McCarthy, J. F., Tschaplinski, T. J. (1991): Biological markers in environmental sentinels to establish exposure to and effects of atmospheric toxicants: an overview. - In: Moser, T.J., Baker, J. R., Tingey, D. T. (Eds). Ecological exposure and effects of airborne toxic chemicals: USA.

[35] McElroy, E., Farrington, J. W., Teal, J. M. (1989): Bioavailability of aromatic hydrocarbons in the aquatic Environment. - In: Varanasi, U. (Ed.) Metabolism of Polycyclic Aromatic Hydrocarbons in the Aquatic Environment. CRC Press Inc. Boca Raton, Florida, USA. 1-39.

[36] Michel, J., Henry, JR., C.B. Thumm, S. (2002): Shoreline assessment and environmental impacts from the M/T Westchester oil spill in the Mississippi River. - Spill Science \& Technology Bulletin 7 (3-4): 155-161.

[37] Mittler, R., Vanderauwera, S., Gollery, M., Van Breusegem, F. (2004): Reactive oxygen gene network of plants. - Trends in Plant Science 9: 490-498.

[38] Ogboghodo, I. A., Iruaga, E. A., Osemwota, I. O., Chokor, J. U. (2004): An assessment of the effects of crude pollution on soil properties, germination and growth of maize (Zea mays) using two crude types - Forcados light and Escravos light. - Environmental Monitoring and Assessment 96:142-152.

[39] Omosun, G., Markson, A. A., Mbanasor, O. (2008): Growth and anatomy of Amaranthus hybridus as affected by different crude oil concentrations. Am-Euras. - Jornal of Scientific Research 3: 70-74. 
[40] Paskova, V., Hilscherovà, K., Feldmannovà, M., Blaha, L. (2006): Toxic effects and oxidative stress in higher plants exposed to polycyclic aromatic hydrocarbons and their $\mathrm{n}$ heterocyclic derivatives. - Environmental Toxicology and Chemistry 25 (12): 3238-3245.

[41] Quinones-Aquilar, E. E., Ferra-Cerrato, R., Gavi, R. F., Fernandez, L., Rodriguez, V. R., Alarcom, A. (2003) : Emergence and growth of maize in a crude oil polluted soil. Agrociencia 37: 585-594.

[42] Rao, M. V., Davis, K. R. (1999): Ozone-induced cell death occurs via two distinct mechanisms in Arabidopsis: the role of salicylic acid. - The Plant Journal 17: 603-614.

[43] Reinhardt, D. H., Rost, T. L. (1995): On the correlation of the primary root growth and treachery element size and distance from the tip in cotton seedlings grown under salinity. - Environmental and Experimental Botany 35: 575-588.

[44] Romero- Puertas, M. C., Corpas, F. J., Rodríguez-Serrano, M., Gómez, M., Del Río, L. A., Sandalio, L. M. (2007) : Differential expression and regulation of antioxidative enzymes by cadmium in pea plants. - Journal of Plant Physiology 164: 1346-1357.

[45] Schreiber, L., Hartmann, K., Skrabs, M., Zeier, J. (1999): Apoplastic barriers in roots: chemical composition of endodermal and hypodermal cell walls. - Journal of Experimental Botany 50: 1267-1280.

[46] Shalini, C., Dubey, R. S. (2003): Lead toxicity induces lipid peroxidation and alters the activities of antioxidant enzymes in growing rice plant. - Plant Science 164: 645- 655.

[47] Shannon, M. C., Grieve, C. M., Francois, L. E. (1994): Whole-plant response to salinity. - In: Wilkinsow, R.E. (ed) Plant-environment interactions. New York.

[48] Sharma, G. K., Chandler, C., Salemi, L. (1980): Environmental pollution and leaf cuticular variation in Kudzu (Pueraria lobata Willd). - Annals of Botany 45: 77-80.

[49] Smith, M. J., Flowers, T.H., Duncan, H.J., Alder, J. (2006): Effects of polycyclic aromatic hydrocarbons on germination and subsequent growth of grasses and legumes in freshly contaminated soil and soil with aged PAHs residues. - Environmental Pollution 141: 519-525.

[50] Song, G. L., Hou, W. H., Wang, Q. H., Wang, J. L., Jin, X. G. (2006): Effect of low temperature on eutrophicated waterbody restoration by Spirodela polyrhiza. Bioresource Technology 97: 1865-1869.

[51] Spies, R. B., Rice, S. D., Wolfe, D. A., Wright, B. A. (1996): The effects of the Exxon Valdez oil spill on the Alaskan coastal environment. - In: Rice, S. D., Spies, R. B., Wolfe, D. A. Wright, B. A. (Eds.). Proceedings of the Exxon Valdez Oil Spill Symposium. Alaska. - American Fish Society Symposium 18: 1-16.

[52] Sun, W., Montagu, M. V., Verbruggen, N. (2002): Small heat shock proteins and stress tolerance in plants. - Biochimica and Biophysica Acta 1577: 1-9.

[53] Thordal-Christensen, H., Zhang, Z., Wei, Y., Collinge, D. B. (1997): Subcellular localization of $\mathrm{H}_{2} \mathrm{O}_{2}$ in plants, $\mathrm{H}_{2} \mathrm{O}_{2}$ accumulation in papillae and hypersensitive response during barley-powdery mildew interaction. - Plant Journal 11:1187-1194.

[54] Vance, C. P., Kirk, T. K., Sherwood, R. T. (1980): Lignification as a mechanism of disease resistance. - Annual Review of Phytopathology 18: 259-288.

[55] Won, E. J., Rhee, J. S., Kim, R. O., Ra, K., Kim, K.T., Shin, K. H., Lee, J. S. (2012): Susceptibility to oxidative stress and modulated expression of antioxidant genes in the copper-exposed polychaete Perinereis nuntia. - Comparative Biochemistry and Physiology 155: 344-351.

[56] Xu, J.G., Johnson, R.L. (1995): Root growth, microbial activity and phosphatase activity in oil-contaminated, remediated and uncontaminated soils planted to barley and field pea. - Plant and Soil 173: 3-10.

[57] Zelko, I., Lux, A. (2004): Effect of cadmium on Karwinskia humboldtiana roots. Biologia 59 (13): 205-209. 